\title{
Perbandingan Kadar Low Density Lipoprotein dan High Density Lipoprotein Antara Akseptor KB Pil Kombinasi dengan Depo Medroksiprogesteron Asetat
}

\author{
Helti Lestari $\mathbf{S}^{1}$, Rauza Sukma Rita ${ }^{2}$, Yusrawati ${ }^{3}$ \\ Pascasarjana IImu Kebidanan Fakultas Kedokteran Universitas Andalas ${ }^{1}$ \\ Bagian Biokimia Fakultas Kedokteran Universitas Andalas ${ }^{2}$ \\ Bagian Obstetri dan Ginekologi Fakultas Kedokteran Universitas Andalas ${ }^{3}$ \\ *e-mail: heltilestari @yahoo.ac.id
}

\begin{abstract}
More than six million women worldwide use contraceptive injection and the popular contraceptive method used is contraceptive pill. Combined pill contraceptives have side effects, which are increased triglyceride and total cholesterol levels and changes in carbohydrate metabolism while the DMPA is irregular menstruation/amenorrhea, weight changes and lipid changes. This research is an observational with Cross Sectional Comparative approach to 36 combination pill acceptor and 36 DMPA acceptor. This study was conducted ini the area of Andalas and Lubuk Buaya Health Center. The sampling method used in this research was simple random sampling method. The analysis was used T-Independent test. The results showed that Low Density Lipoprotein levels DMPA (63,97 $\pm 12,75 \mathrm{mg} / \mathrm{dl})$ vs combined contraceptive pill $(89,66 \pm 28,39 \mathrm{mg} / \mathrm{dl}) \mathrm{p}=$ 0,25 and High Density Lipoprotein levels DMPA $(63,97 \pm 12,75 \mathrm{mg} / \mathrm{dl})$ vs combined contraceptive pill $(60,06 \pm$ $15,57 \mathrm{mg} / \mathrm{dl}), p=0,25$. Results of this study concluded that there was significant difference in average of Low Density Lipoprotein and High Density Lipoprotein levels in the combined contraceptive pill and Medroxy Progesteron Acetate Depot acceptor but statistically the difference was no significant.
\end{abstract}

Keywords:

Combined Contraceptive Pill; DMPA; HDL; LDL

\section{PENDAHULUAN}

Indonesia merupakan negara ke empat berpenduduk paling banyak di dunia setelah Cina, India dan Amerika. Berdasarkan data Badan Pusat Statistik jumlah penduduk Indonesia dari tahun ke tahun mengalami peningkatan, tahun 2010 jumlah penduduk Indonesia mencapai 237,64 juta jiwa, pada tahun 2014 jumlah penduduk Indonesia mencapai 252,20 juta jiwa dengan laju pertumbuhan penduduk Indonesia tahun 20102014 sebesar $1,40 \%$. Salah satu program pemerintah untuk mengatasi jumlah penduduk yang bertambah adalah program Keluarga Berencana (KB). Oleh karena itu, alat kontrasepsi merupakan faktor penting dalam kehidupan seorang wanita dipandang dalam konteks seksual dan kesehatan reproduksi. Peran bidan dalam keluarga berencana diakui oleh World Health Organitation (WHO) dapat memfasilitasi klien melalui pengetahuan dan pilihan dengan memberikan informasi dan saran mengenai keluarga berencana yang baik (Badan Pusat Statistik, 2010 ; Fraser, 2011 ; Badan Kependudukan dan Keluarga Berencana Nasional, 2012).

Saat ini metode kontrasepsi yang biasa digunakan akseptor KB adalah metode kontrasepsi hormonal berupa suntikan Depo Medroksiprogesteron Asetat (DMPA), suntikan KB hormonal kombinasi, oral kontrasepsi serta pemasangan implan subkutan. Menurut Fraser (2011), lebih dari enam juta wanita di seluruh dunia menggunakan KB suntik dan menggunakan pil sebagai metode kontrasepsi yang populer. Hal ini dikarenakan kontrasepsi suntik bersifat aman, sederhana, efektif dan dapat dipakai pada pasca persalinan dan pada KB pil dapat meningkatkan libido, pengobatan nyeri haid dan penyakit endometriosis (Manuaba, 2010).

Survei Demografi Kesehatan Indonesia (SDKI) (2012) menyatakan bahwa Contraceptive Prevalence Rate (CPR) Nasional yaitu KB $61,9 \%$ dan KB Modern 57,9\% yaitu Intra Uterine Device (IUD) $(6,74 \%)$, Medis Operatif Wanita (MOW) (5,53\%), Medis Operatif Pria (MOP) $(0,35 \%)$, implant $(5,70 \%)$, suntik $(55,90 \%)$ dan pil (23,49\%). Jumlah total peserta KB aktif di Kota Padang tahun 2015 berdasarkan data Badan Kependudukan dan Keluarga Berencana Nasional (BKKBN) sebanyak 481.113 peserta dari Pasangan Usia Subur (PUS) sebesar 904.103 dengan metode kontrasepsi yang digunakan sebagai berikut : suntik 260.256 peserta, pil 85.391 peserta, implant 51.666 peserta, IUD 33.199 peserta, MOW 28.410 peserta, kondom 20.926 peserta dan MOP 1.265 peserta, sedangkan jumlah peserta KB aktif sampai bulan September 2016 adalah 69.954 orang dari total jumlah PUS 112.053 dengan metode KB seperti : suntik 37.093 peserta, pil 13.359 peserta, implant 4.104 peserta, IUD 9.277 peserta, MOW 3.098, kondom 2.640 peserta dan MOP 374 peserta (BKKBN, 2016).

Jumlah peserta KB aktif di kota Padang tertinggi berada di wilayah kerja Puskesmas Belimbing yaitu 8.717 peserta, Lubuk Buaya 8.212 peserta dan Andalas 7.213 peserta, dari jumlah peserta KB aktif metode kontrasepsi suntik dan pil merupakan metode kontrasepsi 
yang paling banyak digunakan (Dinas Kesehatan Kota Padang, 2015). Pemakaian kontrasepsi suntik tertinggi berada di wilayah kerja puskesmas Lubuk Buaya yaitu 7.028 peserta dan di puskesmas Andalas yaitu 3.753 peserta. Peserta kontrasepsi pil tertinggi berada di wilayah kerja puskesmas Lubuk Buaya 2.595 peserta (Dinas Kesehatan Kota Padang, 2014).

Efek samping dari kontrasepsi pil kombinasi adalah meningkatkan kadar trigliserida dan kolesterol total dan perubahan metabolisme karbohidrat sedangkan DMPA adalah menstruasi yang tidak teratur/amenore, perubahan berat badan dan perubahan lipid. Hormon progesteron dan estrogen yang terkandung dalam pil kombinasi mempengaruhi peningkatan natrium dan cairan dan pada DMPA yang mengandung progesteron dapat mempengaruhi lapisan lemak dan nafsu makan yang akan mempengaruhi peningkatan berat badan yang berdampak pada indeks massa tubuh (Cunningham G, et al., 2014 ; Glasier, A. Gebbie, A., 2012 ; Fraser, 2011 ; Mayes, PA dan Khathleen, MB, 2012).

Berdasarkan hasil penelitian yang dilakukan oleh Lizarelli et al., (2009) didapatkan kadar Low Density Lipoprotein (LDL) pada kelompok DMPA mengalami penurunan dibandingkan pengguna pil kombinasi dan kelompok kontrol (LDL: DMPA $=85,3 \pm 20,1$ $\mathrm{mg} / \mathrm{dl}$ vs $\mathrm{COC}=106,7 \pm 33,3 \mathrm{mg} / \mathrm{dl}$ vs kontrol $=$ $102 \pm 24,5 \mathrm{mg} / \mathrm{dl}, p=0,01)$. Kadar HDL pada kelompok DMPA memiliki kadar lebih rendah dibandingkan kelompok kontrol dan kelompok pil kombinasi (DMPA $=42,2 \pm 7,2 \mathrm{mg} / \mathrm{dl}$ vs kontrol $=52,4 \pm 14,1 \mathrm{mg} / \mathrm{dl}$ vs $\mathrm{COC}=45,4 \pm 9,1 \mathrm{mg} / \mathrm{dl}$, $p=0,001)$.

Okeke. CU et al. (2011) melaporkan hasil penelitian pada wanita Negeria yang menggunakan kontrasepsi pil kombinasi secara statistik mengalami peningkatan signifikan kadar trigliserida dan LDL, sedangkan wanita yang menggunakan kontrasepsi suntik kadar HDL dan LDL mengalami peningkatan yang berarti. Penelitian yang di lakukan Stecco et al. (2013) terhadap 47 pengguna kontrasepsi pil kombinasi di Brazil menyatakan kadar HDL, kolesterol total, LDL dan VLDL mengalami peningkatan. Hasil penelitian berbeda didapatkan oleh Syed et al. (2002) menyatakan tidak ada perbedaan signifikan pada kadar trigliserida, kolesterol LDL dan Very Low Density Lipoprotein (VLDL) di serum darah pada kelompok wanita dari pengguna kontrasepsi pil.

Berdasarkan hasil penelitian yang dilakukan Fekadie, M. et al. (2016) di Ethopia didapatkan bahwa kadar LDL (111,54 $\pm 36,04$ $\mathrm{mg} / \mathrm{dl}$ ) mengalami peningkatan yang signifikan pada pengguna DMPA sedangkan HDL $(51 \pm$ $7,68 \mathrm{mg} / \mathrm{dl}$ ) mengalami penurunan yang signifikan pada pengguna DMPA dibandingkan dengan kontrol. Yadav BK et al. (2011), pada penelitiannya tentang pengaruh penggunaan jangka panjang dari DMPA terhadap metabolisme lipid pada wanita di Nepal yang telah menggunakan lebih dari 2 tahun menunjukkan kadarLDL $(3,90 \pm 1,10 \mathrm{mmol} / \mathrm{L})$ lebih tinggi daripada non akseptor, sedangkan kadar pada HDL lebih rendah $(1,09 \pm 1,10$ $\mathrm{mmol} / \mathrm{L}$ ). Peningkatan kadar LDL dan penurunan HDL menunjukkan bahwa DMPA dapat menyebabkan perubahan metabolisme lipid yang dapat meningkatkan risiko kardiovaskular.

\section{METODE PENELITIAN}

Desain penelitian ini adalah observasional analitik dengan pendekatan cross sectional yang dilakukan di wilayah kerja Puskesmas Andalas dan Puskesmas Lubuk Buaya dari bulan Desember 2017 sampai dengan Februari 2018. Populasi penelitian ini adalah semua akseptor pil kombinasi dan Depo Medroksiprogesteron Asetat (DMPA) di Wilayah Kerja Puskesmas Andalas dan Lubuk Buaya dengan jumlah sampel 36 pil kombinasi dan 36 DMPA. Teknik pengambilan sampel yaitu simple random sampling dan subjek yang diambil yang memenuhi kriteria inklusi seperti : pemakaian kontrasepsi secara terus menerus dan teratur $>$ 2 tahun, usia 15-49 tahun yang diketahui melalui anamnese dan melihat Kartu Tanda Penduduk, peserta KB pil kombinasi yang diketahui melalui anamnesis, tercatat pada Buku Status Pasien/Kartu KB sebagai akseptor KB DMPA, bersedia untuk mengikuti penelitian dan telah menandatangani formulir persetujuan (Informed Consent).

Variabel independen yaitu akseptor KB pil kombinasi dan DMPA dan variabel dependen yaitu High Density Lipoprotein dan trigliserida. Definisi dan klasifikasi variabel yang diteliti yaitu 1) Low Density Lipoprotein adalah kadar lipoprotein yang berdensitas tinggi dalam serum darah akseptor kontrasepsi pil kombinasi dan DMPA dengan skala ukur rasio 2) High Density Lipoprotein adalah kadar lipoprotein yang berdensitas tinggi dalam serum darah akseptor kontrasepsi pil kombinasi dan DMPA dengan skala ukur rasio. Alat ukur yang digunakan spektrofotometer.

Bahan penelitian ini adalah $3 \mathrm{ml}$ darah vena dari subjek penelitian yang diambil oleh tenaga medis Puskesmas Andalas dan Lubuk Buaya yang dimasukkan ke dalam tabung vacum berisi gel sepator yang berfungsi memisahkan serum dan sel darah, disentrifugasi dan diambil serumnya kemudian diperiksa HDL dan Trigliserida menggunakan kit Diaysis dan pembacaan hasil menggunakan spektrofotometer Microlab 300 pada panjang gelombang $546 \mathrm{~nm}$. 
Uji normalitas data menggunakan uji Shapiro Wilk. Jika distribusi data tidak normal maka dilakukan transformasi data, jika normal maka dilanjutkan dengan uji T-independen. Bila telah ditransformasi, distribusi tidak normal maka menggunakan uji Mann-Whitney. Penelitian ini dilakukan setelah mendapatkan ethical clearance (kelayakan etik) dari komisi etik penelitian Fakultas Kedokteran Universitas Andalas. Etika penelitian yaitu sebelum dilakukan pengambilan darah, subjek diberitahu tentang maksud dan tujuan pengumpulan data serta dijelaskan bahwa penelitian bersifat observasi serta dijelaskan bahwa penelitian bersifat observasi tidak melakukan tindakan intervensi terhadap subjek. Semua keterangan jawaban dan hasil pemeriksaan darah sematamata untuk kepentingan ilmiah dan dijaga kerahasiannya. Meminta kesedian pasien untuk dimintai sampel darah sebanyak $3 \mathrm{ml}$. Sebagai bukti kesedian menjadi subjek penelitian, responden diminta untuk mendatangani lembar informed consent.

\section{HASIL DAN PEMBAHASAN}

Tabel 1 Karakteristik responden berdasarkan umur dan lama pemakaian

\begin{tabular}{|c|c|c|c|}
\hline \multirow[b]{2}{*}{ Karakteristik } & \multicolumn{2}{|c|}{ Akseptor KB } & \multirow[b]{2}{*}{$p$} \\
\hline & $\begin{array}{l}\text { Pil Kombinasi } \\
\text { Rerata } \pm \text { SD }\end{array}$ & $\begin{array}{c}\text { DMPA } \\
\text { Rerata } \pm \text { SD }\end{array}$ & \\
\hline Umur (tahun) & $36,92 \pm 6,93$ & $35,14 \pm 6,27$ & 0,26 \\
\hline Lama Pemakaian (bulan) & $43,14 \pm 12,72$ & $43,78 \pm 11,10$ & 0,82 \\
\hline Berat Badan $(\mathrm{kg})$ & $62,12 \pm 9,66$ & $58,16 \pm 8,87$ & 0,72 \\
\hline
\end{tabular}

Rerata umur akseptor KB pil kombinasi lebih tinggi dibandingkan umur akseptor DMPA disebabkan keterbatasan dan keuntungan alat kontrasepsi seperti pada akseptor pil kombinasi siklus haid lebih teratur dibandingkan DMPA sering ditemukan gangguan haid. Hasil uji statistik tidak terdapat perbedaan disebabkan pil kombinasi dan DMPA dapat digunakan oleh perempuan usia lebih dari 35 tahun sampai perimenopause. Usia responden dibatasi pada usia subur saja karena pada wanita yang telah menopause tidak ada hormon estrogen dan progesteron endogen yang dimiliki, hal ini cenderung mengganggu metabolisme lipid (Crosignani, 2006 : Affandi, Biran, et al., 2014 : Morgan G dan Hamilton C, 2009).

Rerata lama pemakaian kontrasepsi pil kombinasi 43,14 $\pm 12,72$ bulan sedangkan DMPA $43,78 \pm 11,10$ bulan. Uji statistik menunjukkan bahwa tidak terdapat perbedaan yang bermakna antara lama pemakaian akseptor KB pil kombinasi dan DMPA dengan nilai $p>0,05$. Hal ini karena masing-masing kelompok KB mempunyai keuntungan dan keterbatasan (Affandi, Biran, et al., 2014).

Rerata berat badan akseptor KB pil kombinasi $(62,12 \pm 9,66 \mathrm{~kg})$ lebih tinggi DMPA $(58,16 \pm 8,87 \mathrm{~kg})$. Uji statistik menunjukkan bahwa tidak terdapat perbedaan yang bermakna antara lama pemakaian akseptor KB pil kombinasi dan DMPA dengan nilai $p>0,05$. Hal ini sesuai dengan penelitian yang dilakukan Berenson dan Rahman (2010) yang menunjukkan berat badan pada akseptor pil kombinasi $(73,3 \pm 17,7 \mathrm{~kg})$ lebih tinggi DMPA $(71,8 \pm 19,2 \mathrm{~kg})$.
Tabel 2 Perbandingan Kadar LDL dan HDL Antara Akseptor KB Pil Kombinasi dan DMPA

\begin{tabular}{lcccc}
\hline Kadar & $\mathbf{n}$ & $\begin{array}{c}\text { Pil Kombinasi } \\
\text { Rerata } \pm \text { SD }\end{array}$ & $\begin{array}{c}\text { DMPA } \\
\text { Rerata } \pm \text { SD }\end{array}$ \\
\hline $\mathrm{LDL}^{*}$ & 36 & $89,66 \pm 28,39$ & $98,52 \pm 21,56$ & 0,14 \\
$\mathrm{HDL}^{* *}$ & 36 & $60,06 \pm 15,57$ & $63,97 \pm 12,7$ & 0,25 \\
\hline${ }^{*}$ Low Density Lipoprotein & & \\
${ }^{* *}$ High Density Liprotein
\end{tabular}

Rerata kadar LDL antara akseptor KB DMPA $(98,52 \pm 21,56 \mathrm{mg} / \mathrm{dl})$ lebih tinggi dibandingkan akseptor KB pil kombinasi $(89,66 \pm$ 28,39 $\mathrm{mg} / \mathrm{dl}$ ). Hasil uji T-Independent menunjukkan bahwa tidak terdapat perbedaan yang bermakna pada kedua kelompok dengan nilai $p=0,14(p>0,05)$.

Secara statistik menunjukkkan tidak ada perbedaan yang bermakna antara kedua kelompok, hal ini ada beberapa faktor yang mempengaruhi kadar LDL diantaranya hormon, asupan makanan dan pola makanan. Wanita subur yang menggunakan kontrasepsi hormonal menyebabkan hormon estrogen dan progesteron tidak seimbang yang berakibatkan penurunan HDL dan peningkatan LDL. Menurut Nugroho (2011), sebagai kontrasepsi progesteron menghambat kerja estrogen dan mempunyai efek androgenik yang dapat meningkatkan kerja enzim lipase hepatik sehingga konversi IDL menjadi LDL meningkat (Dasuki et al, 2008 ; Nugroho, 2011).

Berdasarkan hasil penelitian yang dilakukan Fekadie, M. et al. (2016) didapatkan kadar LDL (111,54 $\pm 35,04 \mathrm{mg} / \mathrm{dl})$ pengguna DMPA lebih tinggi dibandingkan kadar LDL $(83,26 \pm 30,96 \mathrm{mg} / \mathrm{dl})$ pada kelompok kontrol. Sejalan dengan penelitian yang dilakukan Yadav BK et al (2011) di Nepal menunjukkan kadar LDL pada DMPA $(3,90 \pm 1,10 \mathrm{mmol} / \mathrm{L})$ lebih tinggi dibandingkan kontrol $(2,50 \pm 0,70 \mathrm{mmol} / \mathrm{L})$. Namun secara statistik penelitian ini berbeda 
menunjukkan ada perbedaan yang bermakna antara DMPA dan kontrol dengan nilai $p=0,001$. Berdasarkan penelitian yang dilakukan oleh Sheraya, $N$ (2014) menyatakan adanya hubungan asupan serat makanan dengan kadar kolesterol total dan LDL karena yang mengkonsumsi serat (<29 g/hari) mempunyai kadar LDL yang tinggi dibandingkan dengan mengkonsumsi serat (>29 g/hari). Serat berfungsi menurunkan kolesterol LDL, hal ini sangat penting karena dapat menghambat oksidasi.

Berdasarkan penelitian Al-Yaouzbaki (2011) menunjukkan bahwa tidak terdapat perbedaan kadar LDL yang signifikan antara pengguna DMPA dan bukan DMPA. Kolesterol LDL sendiri merupakan lipoprotein yang bertanggung jawab membawa serum kolesterol ke dalam sel-sel pembuluh darah. Fungsi ini menyebabkan kolesterol LDL merupakan salah satu pertanda untuk penyakit kardiovaskuler seperti penyakit jantung koroner.

Hasil penelitian Capewell (2010) di Amerika Serikat (2010) menunjukkan peningkatan risiko Penyakit Jantung Koroner (PJK) sebanding dengan peningkatan LDL. Setiap penurunan LDL sebesar $1 \%$ dapat mengurangi risiko terjadinya penyakit kardiovaskuler sebesar 1\%. Penurunan kolesterol total sebesar 3-4\% sangat bermakna secara klinis, karena setiap penurunan $1 \%$ kolesterol serum dapat menurunkan 2-3\% risiko terkena PJK. Berdasarkan penelitian ini menunjukkan bahwa ada korelasi yang tinggi antara kadar LDL dengan kadar kolesterol total, karena dua pertiga dari kolesterol total biasanya diangkut sebagai kolesterol dalam LDL.

Rerata kadar HDL akseptor DMPA (63,97 \pm $12,75 \mathrm{mg} / \mathrm{dl}$ ) lebih tinggi dibandingkan akseptor KB pil kombinasi $(60,06 \pm 15,57 \mathrm{mg} / \mathrm{dl})$. Hasil uji statistik menunjukkan bahwa tidak terdapat perbedaan yang bermakna antara kadar HDL akseptor KB pil kombinasi dan DMPA dengan nilai $p>0,05$.

Tidak ada perbedaan kadar HDL antara akseptor KB pil kombinasi dan DMPA disebabkan adanya faktor peningkatan berat badan, hormon, aktivitas fisik, asupan makanan dan pola makan yang dikonsumsi responden penelitian. Hormon yang terkandung dalam pil kombinasi dapat meningkatkan natrium dan cairan sedangkan hormon yang terkandung dalam DMPA dapat meningkatkan nafsu makan dan lapisan lemak sehingga mengakibatkan peningkatan berat badan. Rata-rata peningkatan berat badan akseptor pil kombinasi (62,12 \pm 9,66) mengalami peningkatan dibandingkan akseptor DMPA $(58,16 \pm 8,87)$. Peningkatan berat badan ini akan mempengaruhi peningkatan massa dan aktivasi CETP sehingga mempengaruhi penurunan kadar HDL (Adam J,
2006 ; Rashid Shirya and Genest Jacques, 2007).

Umur dapat mempengaruhi profil lipid semakin tua seseorang maka terjadi penurunan berbagai fungsi organ tubuh sehingga keseimbangan profil lipid darah sulit tercapainya akibatnya kadar trigliserida, kolesterol total dan LDL meningkat dan kadar HDL menurun. Kadar HDL akseptor DMPA meningkat dibandingkan pil kombinasi disebabkan oleh usia pada akseptor DMPA lebih rendah dibandingkan dengan akseptor pil kombinasi. Hasil penelitian menunjukkan umur akseptor DMPA (35,14 \pm 6,27 tahun) lebih rendah dibandingkan umur akseptor pil kombinasi (36,92 \pm 6,93 tahun) (Guyton AC, 2008 ; Mayes, PA dan Khathleen, $\mathrm{MB}, 2012)$.

Hasil penelitian yang dilakukan pada 83 wanita di Nigeria oleh Okeke CU et al. (2011) menunjukkan kadar HDL pada DMPA (2,53 \pm $0,17 \mathrm{mmol} / \mathrm{L})$ lebih tinggi dibandingkan akseptor pil kombinasi $(2,07 \pm 0,25 \mathrm{mmol} / \mathrm{L})$ dengan nilai $p>0,05$ sehingga secara statistik tidak terdapat perbedaan antara pil kombinasi dan DMPA. Hal ini terjadi karena efek dari hormon yang ada pada kontrasepsi oral. Penelitian yang sejalan yang dilakukan Asare GA, et al di Ghana menunjukkan kadar HDL pada akseptor KB suntik $(1,35 \pm 0,39 \mathrm{mmol} / \mathrm{L})$ lebih tinggi akseptor $\mathrm{KB}$ pil (1,3 $\pm 0,25 \mathrm{mmol} / \mathrm{L})$.

Berdasarkan hasil yang dilakukan $F$, Yesmin et al, (2013) pada 30 wanita menggunakan kontrasepsi pil kombinasi menunjukkan kadar HDL (37,93 $\pm 10,63 \mathrm{mg} / \mathrm{dl})$ lebih rendah dibandingkan kontrol $(44,40 \pm 5,01$ $\mathrm{mg} / \mathrm{dl})$ dan mengalami penurunan hal ini disebabkan karena pengaruh komponen progesteron yang ada di dalam pil kombinasi sehingga aktivitas enzim hepatik lipase meningkat. Berdasarkan hasil penelitian yang dilakukan Zhou, Q, et al (2015) peningkatan konsumsi tinggi serat dari $<18$ gr/hari sampai $>30 \mathrm{~g} /$ hari dapat meningkatkan kadar HDL ratarata sebesar $10,1 \%$ sedangkan kadar kolesterol total dan LDL menurun sebesar 11,1\% untuk perempuan. Semakin banyak LDL dalam plasma maka makin sedikit kadar HDL. HDL berfungsi penyerapan kolesterol dari makrofag yang mempunyai dua jalur yaitu langsung ke hati dan jalur langsung melalui VLDL dan IDL untuk membawa kolesterol kembali ke hati untuk disekresikan ke empedu, dengan ini berhubungan dengan menurunnya insiden penyakit aterosklerotik (Adam J, 2006 ; Champ, 2010). 


\section{Persamaan IImiah}

$$
n_{1}=n_{2}=2\left[\frac{\left(Z_{\alpha}+Z_{\beta}\right) S}{\left(X_{1}-X_{2}\right)}\right]
$$

Keterangan :

$\mathrm{n}$ : besar sampel

$Z_{\alpha}$ : kesalahan tipe I $(\alpha)$ sebesar $5 \%=1,96$

$Z_{\beta}$ : kesalahan tipe II $(\beta)$ sebesar $20 \%=0,842$

$S$ : simpangan baku kedua kelompok

$\left(\mathrm{X}_{1}-\mathrm{X}_{2}\right)$ : perbedaan secara klinis dianggap penting (Clinical Judgement)

\section{SIMPULAN}

Terdapat perbedaan kadar LDL dan HDL antara akseptor pil kombinasi dan DMPA namun secara statistik tidak terdapat perbedaan yang bermakna.

\section{DAFTAR PUSTAKA}

Adam J. (2006). Buku Ajar Ilmu Penyakit Dalam (Edisi IV Jilid III). Dalam : Hormon Steroid. Jakarta : Departemen IImu Penyakit Dalam Fakultas Kedoteran UI Editor : Sudoyo AW, et all.

Al-Youzbaki, WB. (2011). C-Reactive Protein and Lipid Profile Among Depo Medroxyprogesteron Acetat Injection Users. Annals of the College of Medicine. vol. 37 no. 1 and 2. pp. 48-56.

Asare, AG. Santa, S. Ngala, AF. Afriyie, D. Amoah, A.GB.(2014). Effect of hormonal contraceptives on lipid profile and the risk indices for cardiovaskuler disease in a Ghanaian Community. International Journal of womens Health. vol.6. pp. 597603.

Badan Pusat Statistik. (2010). Laju Pertumbuhan Penduduk. http://www.bps.go.id/

BKKBN. (2012). Laju Pertumbuhan Penduduk. http://www/bkkbn.go.id/

BKKBN.(2016). Analisis dan Evaluasi Pengendalian Lapangan. Padang

Capewell, S. Ford, ES. Croft, JB. Critchley, JA. Greenlund, JK. Labarthe, DR.(2010). Cardiovascular Risk Factor Trends and Potential for Reducing Coronary Heart Disease Mortality in the United States of Amerika. Bulletin of the World Health Organization. Vol.88 No.2. pp. 4-82. doi : 10.2471/blt.08.057885.

Champ, PC. Harvey, RA. Denise, RF.(2010). Biokimia : Ulasan Bergambar (Edisi 3). Jakarta: EGC.

Cunningham G., Leveno R.J., Bloom S.I. et al (2014). Obstetri Williams. (Terjemahaan : Pendit, BU. Dimanti, A. Chairunnisa. Mahanani, DA. Yesdelita, N. Dwijayanthi, L. et a).Jakarta : EGC
F, Yesmin. CR, Sarkar. AZ, Zahid, A, Ahmed, MS, Hossain.(2013). Lipid Profile in Oral Contraceptives User Women. Dinajpur Med Col J. Vol.6 no.1. pp. 54-57.

Fekadie, M. Seifu, D. Kumpi, S. Kokeb, A. (2016). Effect of DepoMedroxyprogesteron Acetate (DMPA) on Lipid Metabolism. International Journal of Reaserch in Biotechnology and Biochemistry. Vol.6 no.1. pp. 6-11.

Fraser, DM (eds.).(2011). Myles Textbook for Midwives (Edisi 14). Jakarta : EGC.

Gilman, AG (ed.).(2012). Dasar Farmokologi Terapi (Edisi 10) Volume 4. Dalam : Estrogen dan Progesteron, LooseMitchell, DS dan M. Stancel George. Jakarta : EGC. pp. 1567-1604.

Glasier, Anna.(2012). Keluarga Berencana dan Kesehatan Reproduksi (Edisi 4). Dalam : Kontrasepsi Oral Kombinasi, Guillebaud, Jhon, (Terjemahaan : Brahm U Pendit). Jakarta : EGC. pp. 34-85.

Guyton, AC. Hall, JE. (2012). Buku Ajar Fisiologi Kedokteran (Edisi 11). (Terjemahaan : Irawati. Ramadhani, D. Indriyani, F. Dany, F. Nuryanto, I. Rianti, SSP. et al) Jakarta : EGC.

Jung, UJ dan Chio, MS.(2014). Obesity and Its Metabolic Complication the Role of Adipokines and the Relationship between Obesity, Inflamation, Insulin Resistance, Dyslipidemia and Nonalcoholic Fatty Liver Disease. International Journal of Moleculer Sciences.vol.15. pp.61846223.doi: 10.3390/ijms15046184.

Lizarelli MP, Martins PW, VieiraSC, Soares MG, Franceschini AS, Ferriani AR, Patta CM.(2009). Both a combined oral contraceptive and depot medroxyprogesterone acetate impair endothelial function in young women. $J$. Contraception, 79:3540.

Manuaba, IAC. Manuaba, IBGF. Manuaba IBG. (2010). IImu Kebidanan, Penyakit Kandungan \& KB untuk Pendidik Bidan. Jakarta : EGC

Mayes, PA, Khathleen MB.(2012). Metabolisme Asilgliserol dan Sfingolipid ; Pengangkutan \& Penyimpanan Lipid ; Pengangkutan dan Ekskresi Kolesterol. Dalam : Biokimia Harper (Edisi 27), Alih Bahasa Brahm U Pendit, Jakarta : EGC.

Mohammad, NS. Nazli, R. Khan, MA. Akhtar, T. Ahmad, J. Zafar, Z. (2013). Effect of Combined Oral Contraceptive Pills on Lipid Profile, Blood Pressure and Body Mass Index in Women Of Child Bearing Age. KMUJ. Vol. 5 no.1. pp. 22-26.

Naraya, Shreya. Laksh Miprija, N. Vardya, R. Bai, MR. Sudhe, V Krishnawamy, K. et al (2014). association of Clietary Fiber Intake 
with Serum Total Cholesterol Analow Density Lipoprotein Cholesterol Levels in Urban Asian India adults with Type 2 Diabetes. Indian Journal of Endocrinology and Metabolism. Vol.18.no.5. pp. 624-630.

Okeke, CU. Braide, SA. Okolonkwo, BN. Okafor, R.. Eneh2, PC. Adegoke, A. et al.(2011). Comparative Effect of Injectable and Hormonal Contraceptives on Lipid Profil. European Journal Of Cardiovascular Medicine. vol II. no.1. pp. 20-21. doi : 10.5083/ejcm.20424884.64.

Rashid, Shirya and Genest, Jacques. (2007). Effect of Obesity on High Density Lipoprotein Metabolism. Obesity. Vol. 15 no.12. pp. 2875-2888.

SDKI. (2012). Laporan Pendahuluan. Jakarta.

Sjamsiur, Munaf.(2009). Kontrasepsi Oral. Dalam: Kumpulan Kuliah Farmokologi, Obat-obat Penurun Lipid Darah (Edisi 2). Jakarta : EGC.

Stecco, B. Fumagalli, HF. Franceschini, SA. Marzocchi Machodo, CM. Torqueti Toloi, MR.(2013). The Effect of Different Contraception Drugs on the Lipid Profil Of Brazilian Women. Pharmaceut Anal Acta. Vol. 4 no.208. pp. 1-4. doi: 10.4172/21532435.100028.

Syed, S and Quareshi, MA.(2002). Effect of Hormonal Contraception on Plasma Lipid and Lipoprotein Cholesterol Concentrations. Journal Coll Physicians Surg Pak. vol. 12. no. 10. pp. 593-598.

Ulla M. Anttila, M. Liukko, KM. Rantala, MaijaLiisa. Rautianinem, H. Werner F. Sommer and Mamaers, E.(2011). Effects of a Monophase Combined Oral Contraceptive Containing Nomegesteral and Ethininglesteradiol on Haemotasis Lipids and Carbohydrate Metabolism. The European Journal of Contraception and Reproductive Health Care. vol.16. pp. 444-457.

Yadav, BK. Kumar Gupta, R. Gyawali, P. Shrestha, R. Poudel, B. Sigdel, M.et al.(2011). Effect of long-term Use of Depo Medroprogesteron Acetat on Lipid Metabolisme in Nepalese Women. Korean Journal of Laboratory Medicine. vol. 31. pp. 95-97. doi 10.3343/kjlm.2011.31.2.95.

Zhoun, G. Wu, Jiang. Tang, Jing. Wang, Jia-Ji. Lu, Chu-Hong and Wang, Pei-Xi.(2015). Beneficial Effect of Higher Dietary Fiber Intake on Plasma HDL-C and TC/HDL-C Ration Among Chinese Rural-to-Urban Migrant Workers. International Journal of Envirumental Research and Public Health.vol.12. pp 4726-4738.doi : 10.3390/ijerph120504726. 